\title{
Introduction to the cartographic and sedimentological study of the coverage of the TAHANAOUT BASIN (HIGH ATLAS, MOROCCO)
}

\author{
Farah Abdelouhed ${ }^{1, *}$, Ahmed Algouti ${ }^{1}$, Abdellah Algouti ${ }^{1}$, Idir EL konty ${ }^{1}$, and Aboubakr Ezziyani ${ }^{1}$ \\ ${ }^{1}$ Cadi Ayyad University, Faculty of Science, Department of Geology, Geosciences, Geotourism, Natural Hazards and Remote \\ Sensing Laboratory. Bd. BO 2390, 40000 Marrakech, Morocco
}

\begin{abstract}
This study is carried out on the northern edge of the High Atlas of the MARRAKECH basin. The TAHNAOUT DOUAR SOUR basin belongs to the Atlasic domain which is structured by the Hercynian orogeny, taken up and elevated by the Alpine orogeny, our main goal in this studying is to map the TAHNAOUT DOUAR SOUR basin and to characterize all these geological formations, For this purpose we analysed sedimentary tectonic structures ,made lithostratigraphic sections with description and draw a geological map at scale 1/25000 on a topographic background by used MapInfo platform. As final results, our studying of the TAHANOUT basin consists of two main lithological units: the basement formed by conglomeratic and turbidite deposits (alternating sandstone and pelites), and the lithological unit that forms the cover of the TAHNAOUT basin formed by a red detrital material and, carbonate deposits in some cases depending on the deposition environment, The TAHNAOUT basin is also affected by tectonic activity at the basement and Meso-Cenozoic cover levels [1-2]. Magmatic activity is absent and no trace has been recorded.
\end{abstract}

\section{Introduction}

The high Atlas is a mountain range which extends along $600 \mathrm{Km}$ and from 50 to $150 \mathrm{Km}$ in width. It culminates in the Djebel Toubkal $(4165 \mathrm{~m})$. This chain is oriented from southwest to northeast, it consists of three distinct domains; the High Maritime Atlas (western), the High Atlas of MARRAKECH and the Central High Atlas [3-4]. The MARRAKECH high Atlas is subdivided into two separates zone (1): an axial zone $(4000 \mathrm{~m})$ with Paleozoic and Precambrian material, and (2) a zone of the Triassic High plateaus $(2000 \mathrm{~m}-2500 \mathrm{~m})$. The northern sub-Atlasic zone (1000m-1500m). The with Mesozoic and Cenozoic cover and the sub-Atlasic zone extends the depression of the HAOUZ of MARRAKECH. The latter can be subdivided into a high piedmont (800 to $1000 \mathrm{~m}$ ) [5]. The study area, in terms of Atlasic tectonics, belongs to the TNFZ (Tizi N'Test's Fault Zone) [6]. The TAHANAOUT basin is leaning against the first Paleozoic escarpments of the High Atlas of MARRAKECH. Its sedimentary loading is mainly attributed to the Triassic period, some very localized outcrops. In another context, it is related to the Permian [7]. In general, a Meso-Cenozoic series lies in a clear discordance, marked at the base by a pellicular claycarbonate platform of Lias [8]. The observed silico-clastic sedimentation shows an outcrop analogy in terms of simple lithostratigraphic components.

\section{Methodology}

To make a cartography of the basin (TAHNAOUT DOUAR SOUR) in the northern edge of the high Atlas of MARRAKECH, to achieve a lithological and tectonic study, and also to reconstitute the paleo environment of the area, we have adopted some techniques:

- Studying the nature of the contact between the base and the cover,

- Studying the relation between the various formations of the cover met,

- Analyzing the sedimentary tectonic structures and the realization of the

- lithostratigraphic logs with description,

- Creating a geological map at a scale of 1/25000 on a topographic background, and on a MapInfo platform.

\subsection{Geographical setting}

The study area belongs to the sub Atlasic zone of the MARRAKECH high Atlas. The latter is between the DEMNATE accident in the east and the ARGANA corridor in the west. It is an ancient block with reduced Mesozoic to Cenozoic series. It is affected by the orogenesis Hercynian then carried over by the Alpine orogeny [9]. This region belongs administratively to the province of HAOUZ(Fig.1). 


\subsection{Geological setting}

In the paleogeographic level, the DOUAR SOUR basin is located in the intermediary of two basins which are the subject of several studies. It begins from the east of the OURIKA basin to the west of the ARGANA basin. The DOUAR SOUR basin lands are of Paleozoic age (Upper Visian) and Meso-Cenozoic, it's separated by a clear discordance that materializes two different geological times [10]. In the northern flank of the High Atlas of MARRAKECH where the study area is located, four distinct morphological units can be identified [4], which succeed one another from north to south in the following order, The HAOUZ plain. It Is formed from materials resulting the dismantling of the Atlasic chain (molasses) during the Mio-Pliocene and Quaternary. The subatlasic zone. It is considered as the hilly zone; it is made up of the more recent paleogenetic terrains. The high plateaus area. It is formed by Permo-Triassic terrains, with a tabular structure with outcrops of Paleozoic terrain (Visian). The axial zone is a zone where the vertical, the ascent is important, it is constituted by Cambrian to Precambrian terrains (the basement) (Fig. 2).

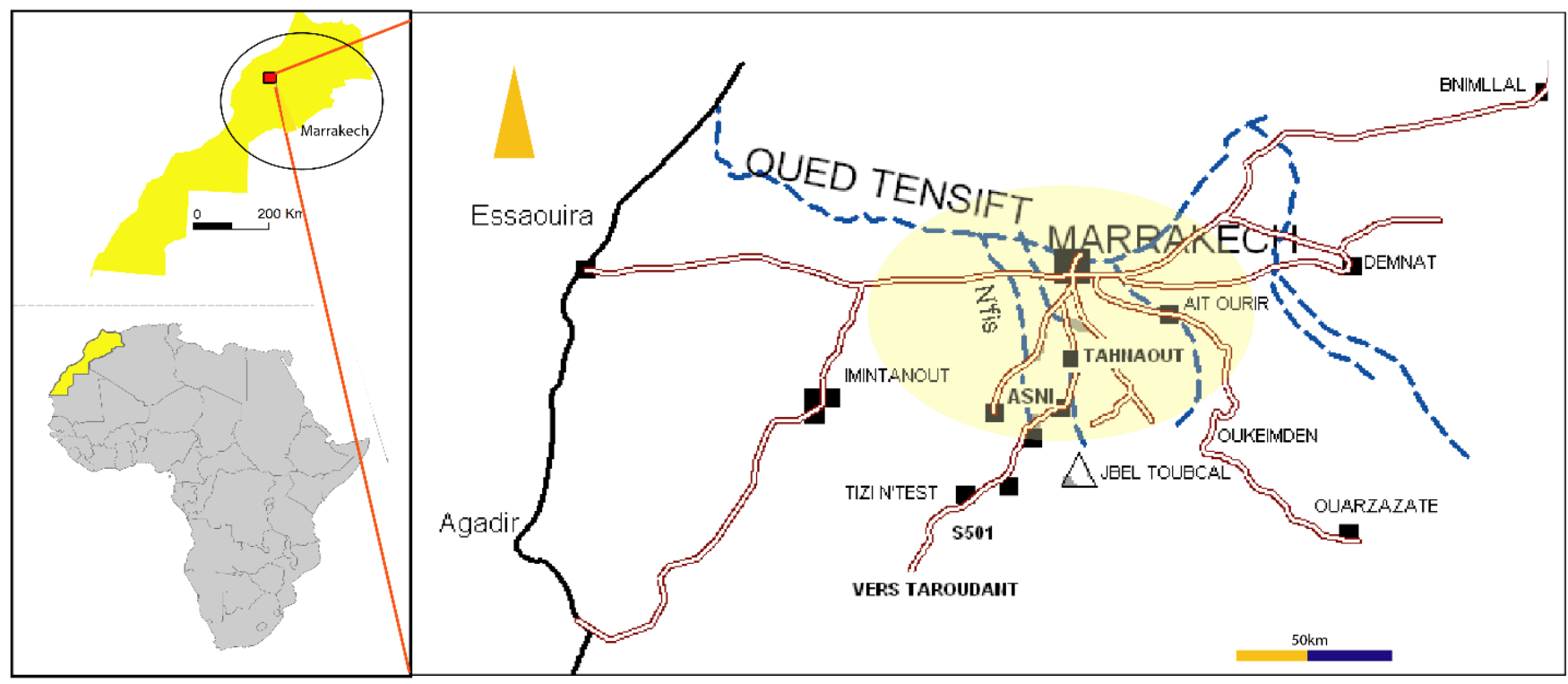

Fig. 1. Geographical location of the study area, the left map shows the large location (African and Moroccan scale), the right map shows the study area in the HAOUZ province.

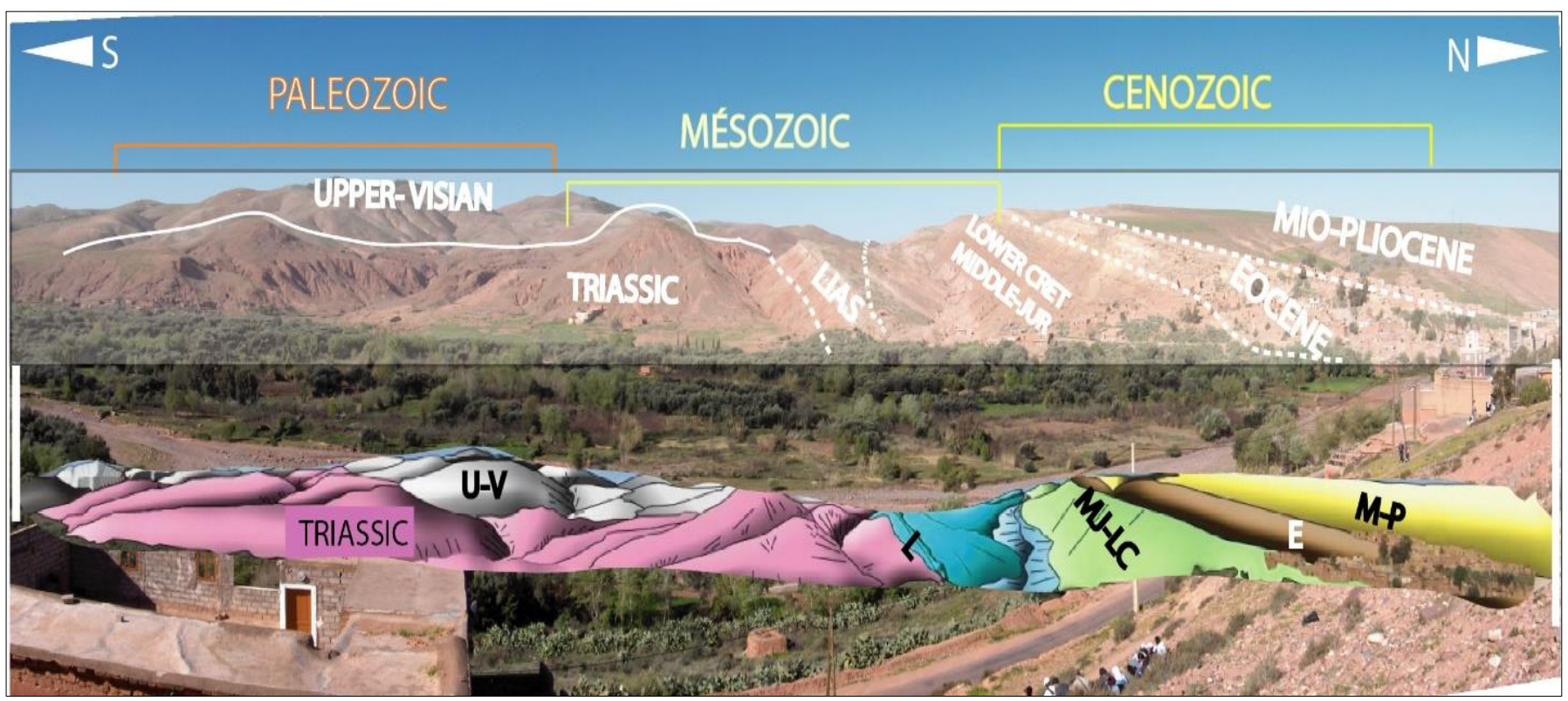

Fig. 2. Panoramic view of the different studied sedimentary series; from the oldest (Upper Visian) on the left of this figure to the most recent on the right of the same figure (Mio-Pliocene). 


\section{Results and discussion}

The geological contours of the cover layers are rectilinear and parallel to each other. The direction of the dip is indicated by the succession of geological layers from the earliest to the most recent. As a result, the basin of DOUAR SOUR TAHANAOUT has a monoclinal structure that has been verified by stratification measurements. Besides, there is the presence of unconformities between the sedimentary series (Fig.2, Fig.3). First An angular discordance D1, on a monoclinal tilted and eroded series of Visian. Second a minor angular discordance D2 between the Trias and the Lias due to the sea level variation. The third unconformity, D3, is a ravine unconformity appearing on the map by triple points that make direct contact between Middle JurassicLower Cretaceous, Eocene and Mio-Pliocene facies, this form of discordance is the result of paleovalley activity (Fig.3, Fig.4)

\subsection{Lithostratigraphy}

\subsubsection{Basement}

Field mapping shows a greyish outcrop of basement to the south in this study area, it is of an Upper Visian age. [11-
12]. The upper limit of the Visian basement is materialized by the Taseksout boundary fault grade (Appendix pic. A \& B) and which corresponds to an angular unconformity. TheVisian basement is subdivided into three formations, from the base to the top Formation 1 a detrital nature that consists of a conglomeratic series followed by a sandstone and silt series. The lithology of this formation indicates a high-energy marine environment (platform) Formation 2; is characterized by rhythmic turbiditic deposits alternating with sandstone and pelites, it is a deep marine deposit. Formation 3 is a chaotic formation observable in the bridge of Oued Ghighaya, and it contains large carbonate olistoliths resulting from the dismantling of the anti-Visian formations. The succession of basement facies indicates the evolution of a progressively deeper subsidiary basin (Fig. 5).

\subsubsection{The cover}

The cover is angularly discordant on the base considering the lithological contrast in the cover and the nature of the boundaries among the different units. Two units have been dignified; a Triassic unit and a post-Triassic unit.

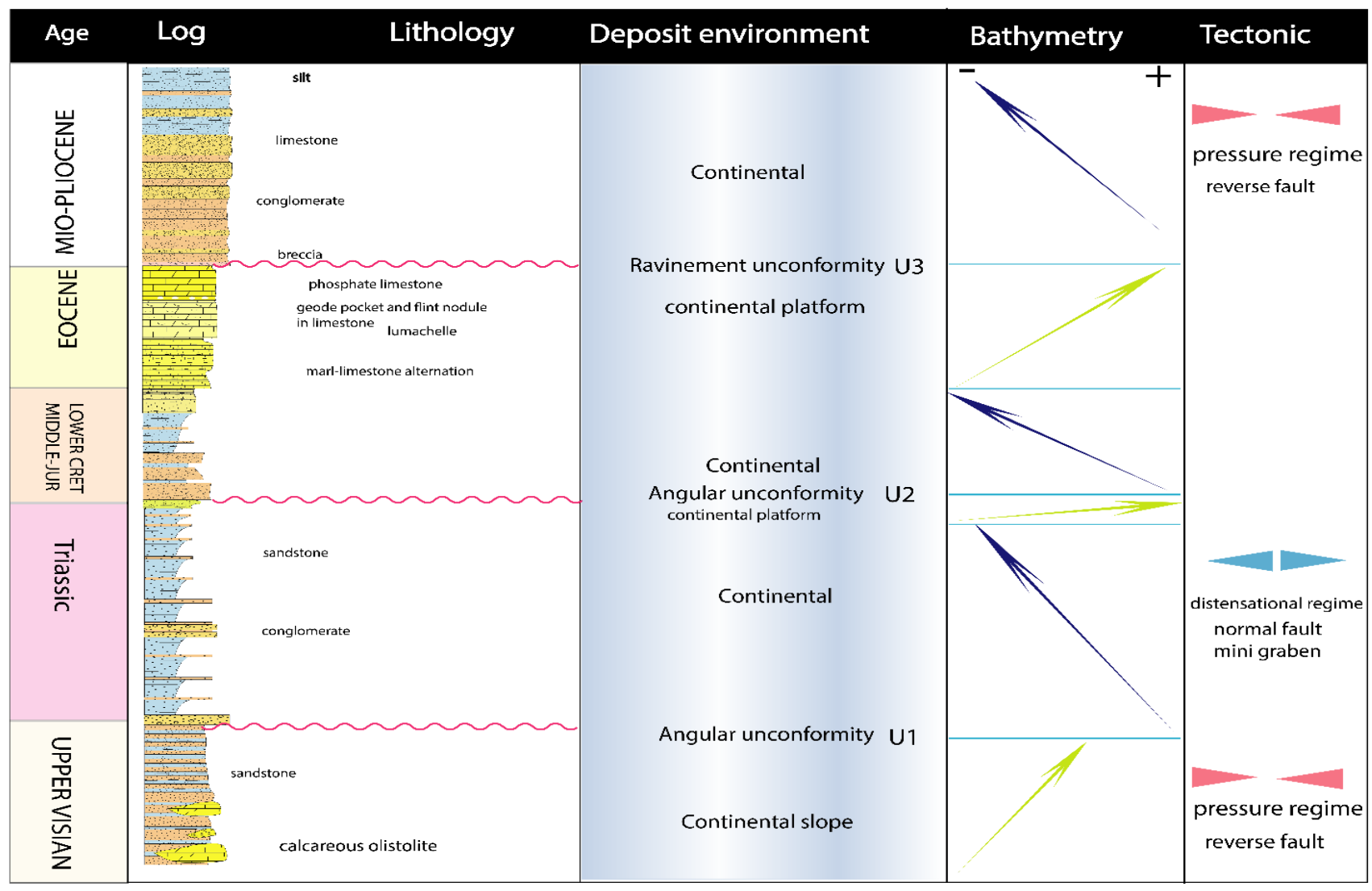

Fig. 3. General schematization of the results obtained in the TAHNAUT basin. 

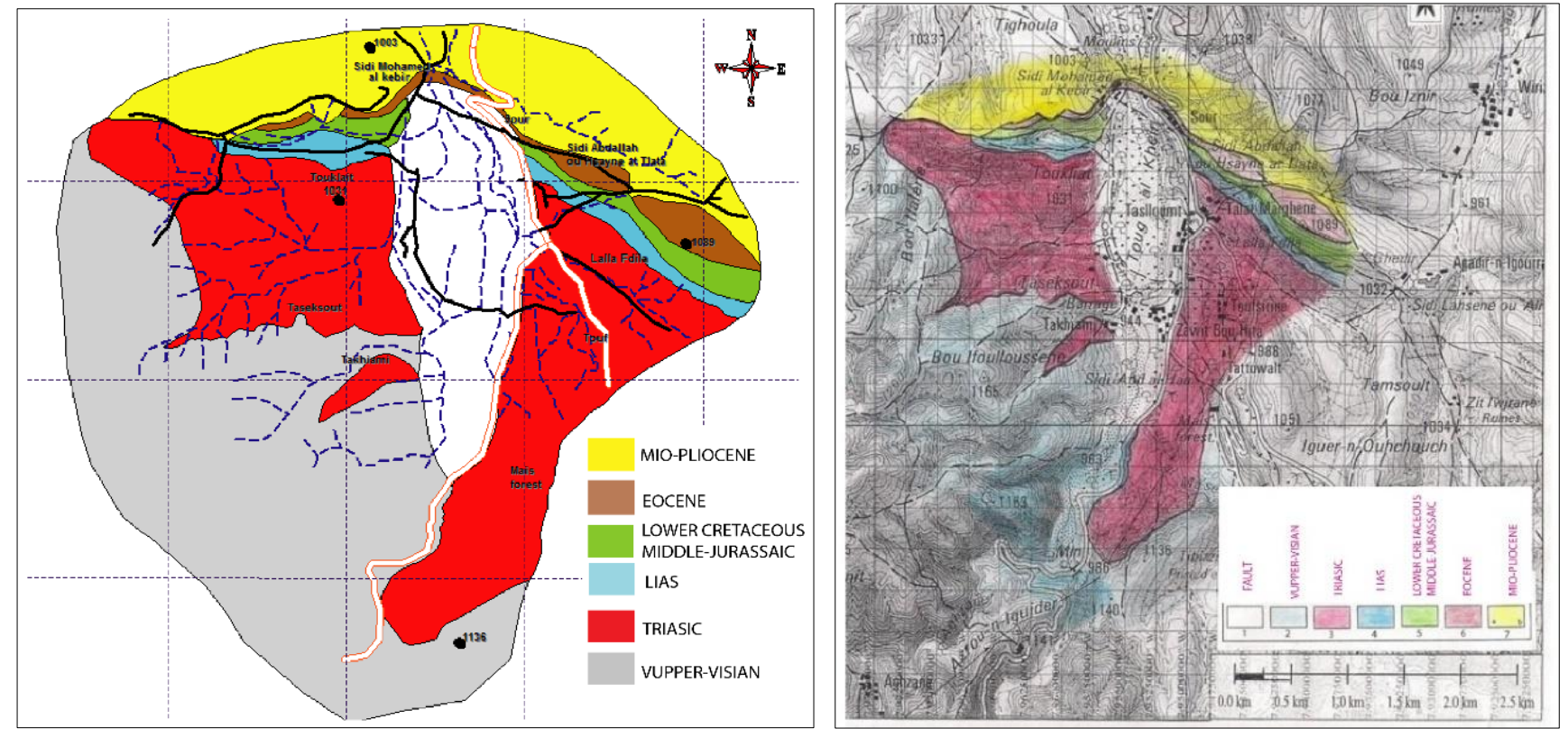

Fig.4. On the right of the figure transfer of field measurements and data on a topographic background by drawing the contours of all geological formations (geological map), on the left of the figure geological map created on MapInfo on the basis of the map created in the field.

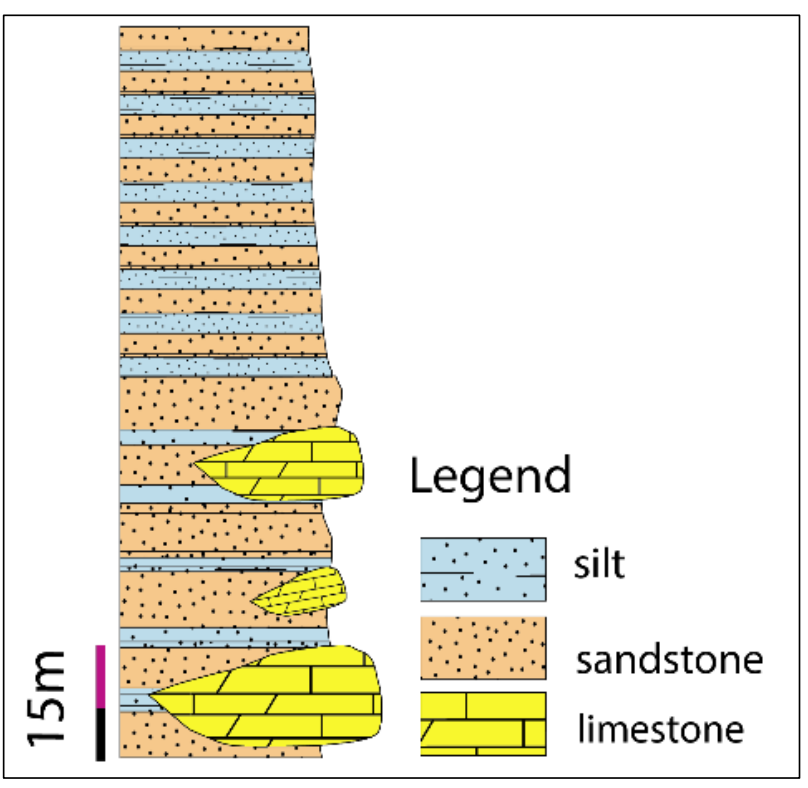

Fig. 5. Synthetic stratigraphic log of the upper Visian

\section{a. Trias}

A panoramic view of the DOUAR SOUR region of TAHANAOUT is good enough to delimit a vast red outcrop rich in iron oxides, it's the Triassic series. It is essentially detrital composed of the following terms: the base composed of polygenic conglomerate whose figurative elements come from the base, surmounted by levels of silty sandstone deposited in the channels (Appendix pic E \& C). Alternatively, sandstones and siltstones, a coarse material, consist of conglomerates and conglomeratic sandstones.
The trias show Formation 4 contains silty sediments and evaporites. Triassic deposits are organized in sequences, starting with coarse elements and ending with fine elements. It is a large continental fill sequence where the depositional environment evolves from an alluvial cone to a deltaic plain. The climate is arid, favoring the precipitation of evaporites under a reduced slice of water. A comparative study based on the bibliography shows the absence of top terms in the series, especially the finite-Triassic basalts (Fig.6), as opposed to the Ourika basin [5].

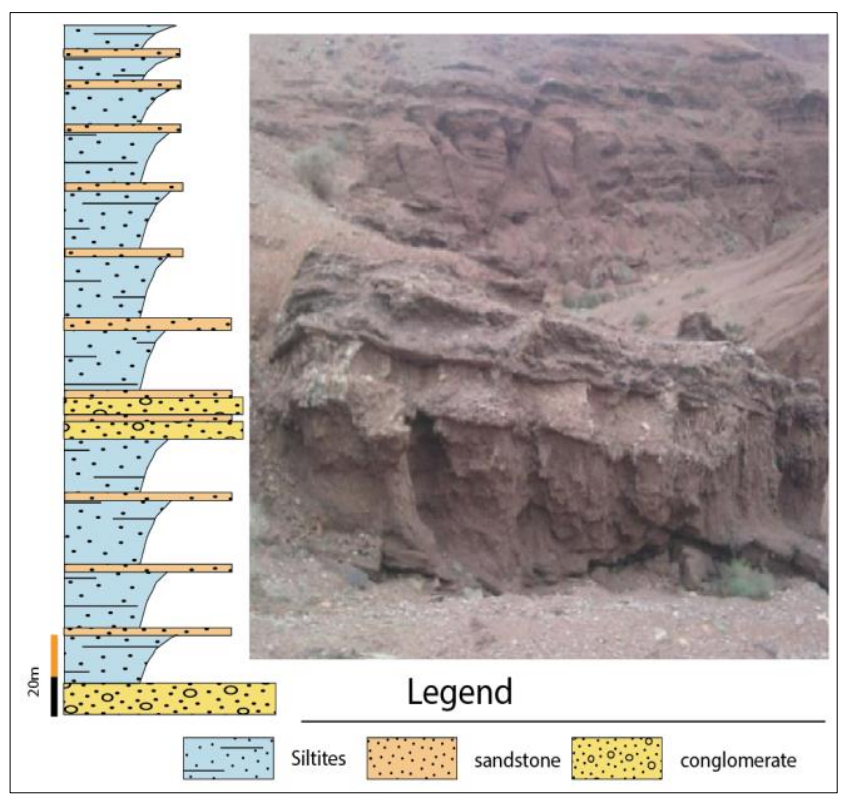

Fig. 6. Synthetic stratigraphic log of Triassic 


\section{b. Lias}

The Lias that rests in slight angular discordance on the Trias, consists of two parts, the basal part, forms a carbonated $3 \mathrm{~m}$ thick limestone slab composed of limestone, marl and sandstone limestone. The whole is stratified in the N110$20^{\circ} \mathrm{N}$ plane. The carbonate slab of the Lias contains sedimentary figures; namely the desiccation cracks, the dissolution voids, and symmetrical ripples which indicate a N39 direction of the paleocurrent. On the other band, the top part, it forms $34 \mathrm{~m}$ thick consisting of evaporites and silty clays with the presence of bipyramidal quartz, this mineral is an indicator of vadose environments and therefore a decrease in the water slice. The facies of the Lias draw a Decreasing grain size and the increasing grain size series which show a change in bathymetry from a deep to a shallower environment, it is a transgression (Fig. 7).

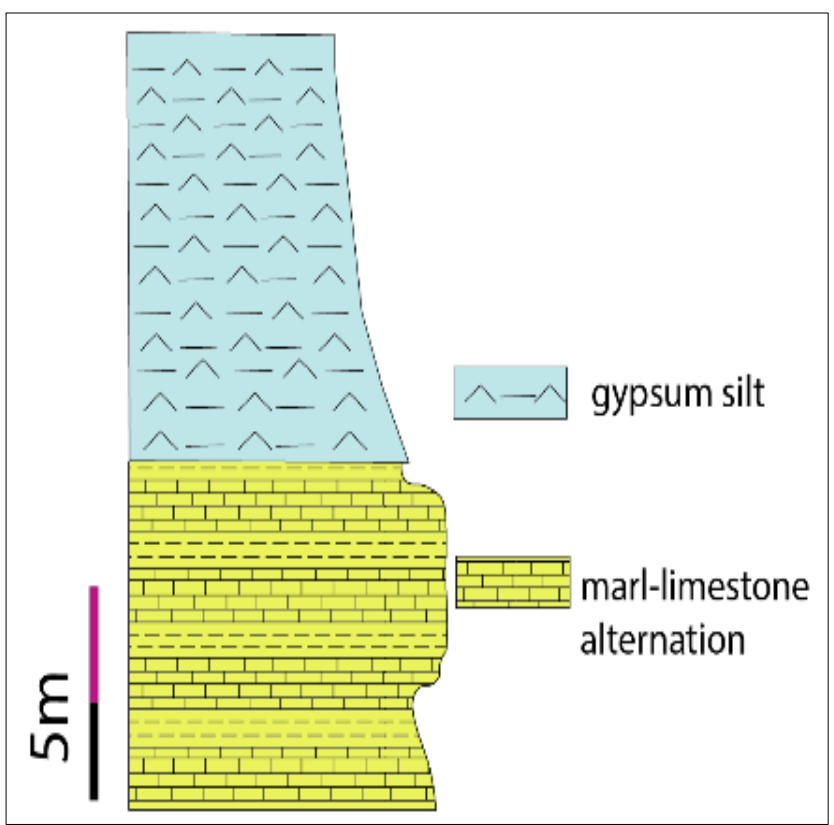

Fig. 7. Synthetic stratigraphic log of the Lias.

\section{c. Middle Jurassic-Lower Cretaceous}

The middle Jurassic-Lower Cretaceous is a red detrital series about $70 \mathrm{~m}$ in thickness based in coincidence on the Lias. It is composed of silts at the base with intercalations of sandstone banks that are getting thicker and thicker and which present a gravelly aspect. The sedimentary figures are under 20 forms of ripples and crisscrossing bedding that indicate channel deposits. The paleocurrent corresponding to sedimentary figures encountered in an ENE direction. At the top, we can see micro conglomeratic deposits structured in sequences of metric repeating flutes and containing cast flutes (Fig. 8). The end of the series is marked in yellow marls. The depositional environment corresponds to a fluvial continental domain flooded by the sea towards the beginning of the Cretaceous. [13]

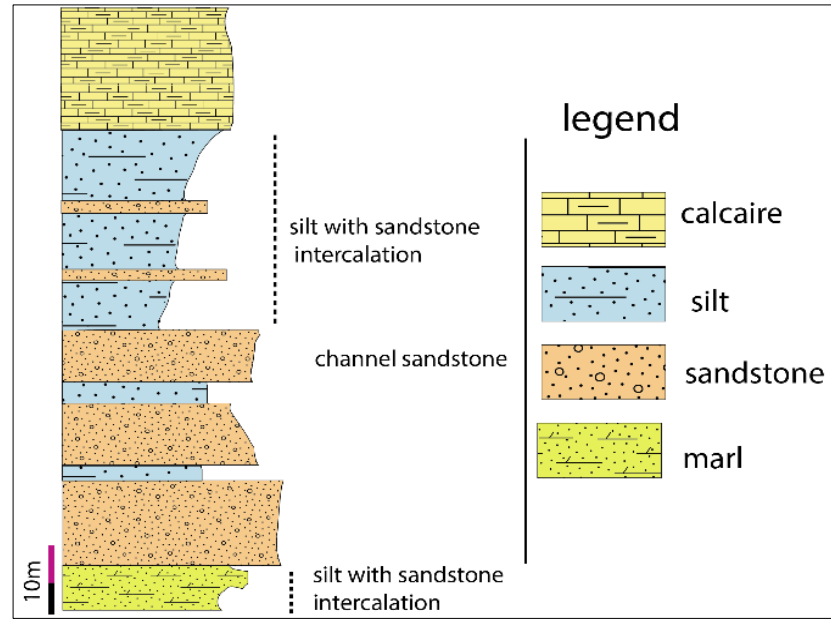

Fig. 8. Synthetic Jurassic Middle-Lower Cretaceous stratigraphic $\log$

\section{d. Eocene}

The DOUR SOUR Eocene is represented by a $15 \mathrm{~m}$ thick carbonate bar, laminated in the $\mathrm{N} 115-30^{\circ} \mathrm{N}$ plane. Measurements of the stratification confirm the concordant contact with the previous series. The lithological and paleontological content of the carbonate bar subdivides it into three facies: (Fig. 9) Phosphatic sandstone limestones, Lithic limestones with stromatolites and evaporites, and Lumachels shell debris limestones (Appendix pic. D). Eocene facies suggest a platform-type environment with a known sea level of flocculation's marked by repeating lumachels levels. (Fig. 9)
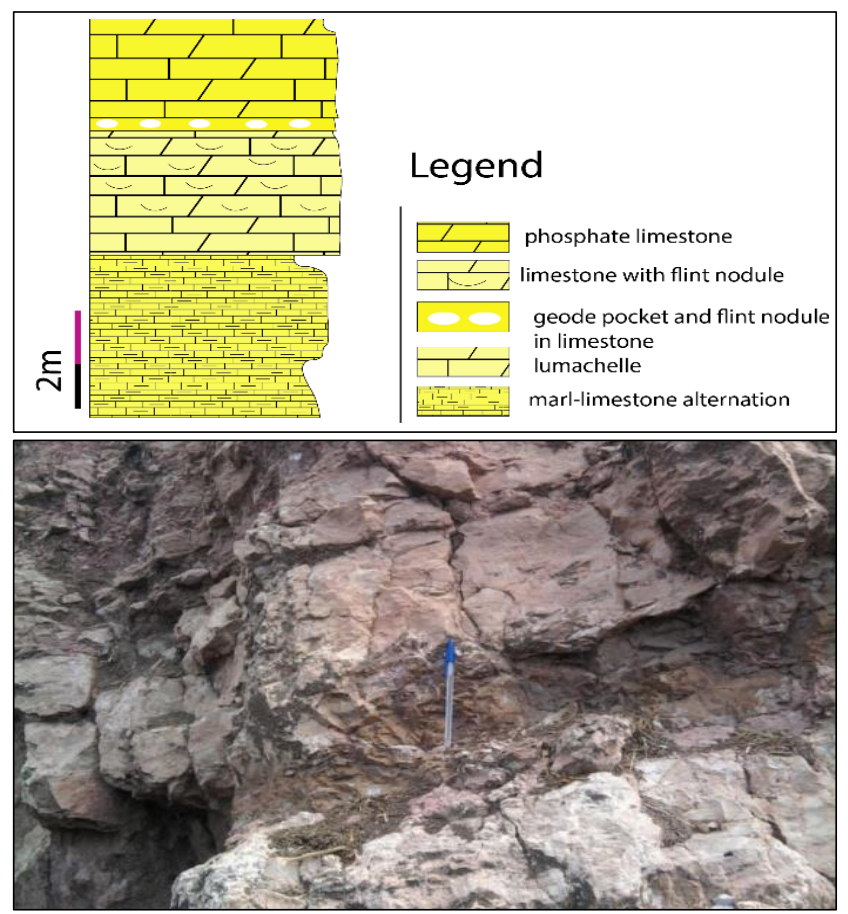

Fig.9. Synthetic stratigraphic log of Eocene 


\section{e. Mio-pleocene}

The Mio-Pleocene is a detrital series whose lower limit is constituted by breccias from the erosion of the Eocene. At the scale of the outcrop, the nature of the Eocene MoiPliocene contact is a gully unconformity marked by the beveling of the carbonate bar at the paleo-valley (Appendix pic. A). The continental deposits of the Moi-Pliocene consisting mainly of micro conglomerates, sandstones and siltites occupying a dozen meters. (Fig. 10) [14].

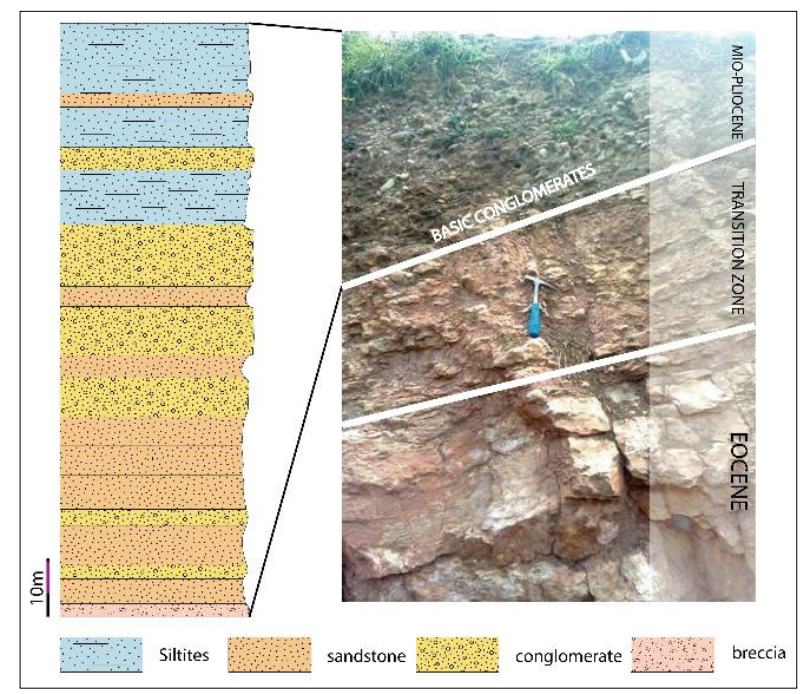

Fig. 10. Synthetic stratigraphic log of the Moi-Pliocene.

\section{Conclusion}

To sum up, the structure of the DOUAR SOUR TAHANAOUT basin was explained in the general context of plate tectonics. However, the permo-Triassic distension accompanied by the dislocation of Pangaea resulted in a subsidence trench in which the Triassic sediments were deposited. The Sea level flocculation will generate transgressive periods that favor carbonate deposits while regressive periods are characterized by red detrital deposits and gaps. After a tectonic stability of Lias towards the end of the Eocene, compressive stresses will herald the beginning of the contemporary alpine tightening at the opening of the southern Atlas.

Acknowledgements. I would like to thank the staff of SEMLALIA's Faculty of Science in general and I would like also to thank the professors of the Geology Department for their help and efforts during the field missions and also during the writing of this article.

\section{References}

1. Proust, F., \& Taponier, P. (1973). L'accident du Tizi n'Test (Haut Atlas-Maroc): décrochement tardi- hercynien repris par la tectonique alpine: 1ère Réuni. Ann. Sci. Terre, 350.

2. Boummane K. (1991) - Le contrôle des accidents hercyniens et tardi-hercynien sur l'évolution des bassins carbonifères et triasiques de la bordure nord de Douar Sour (Haut Atlas de Marrakech).

3. Moret, L. (1931). Recherches géologiques dans l'Atlas de Marrakech. Protectorat de la République française au Maroc Direction générale des travaux publics Service des mines et de la carte géologique.

4. Biron, P., \& Courtinat, B. (1982). Contribution palynologique à la connaissance du Trias du Haut-Atlas de Marrakech, Maroc. Geobios,15(2), 231-235.

5. Salomon, J., Chellai, E. H., Guerra oui, F., \& Lang, J. (1996). Dynamique sédimentaire et structuration, durant le Néogène, de la bordure nord du Haut Atlas Marocain (Haouz de Marrakech). Journal of African Earth Sciences, 22(3), 323-334.

6. Michard, A., Hœpffner, C., Soulaimani, A., \& Baidder, L. (2008). The variscan belt. In Continental evolution: The geology of Morocco (pp. 65-132). Springer, Berlin, Heidelberg.

7. Beauchamp, J. \& Petit, J.P. (1983). Sédimentation et pathogenèse triasique au Maroc : L'exemple du Haut Atlas de Marrakech. Bull. Centre Rech. Explor. Elf. Aquitaine, 7 : 389-397

8. Leblanc, M., \& Lancelot, J. R. (1980). Interprétation géodynamique du domaine panafricain (Précambrien terminal) de l'Anti Atlas (Maroc) à partir de données géologiques et géochronologiques. Canadian Journal of Earth Sciences, 17(1), 142-155.

9. Ferrandini, J. et Ferrandini, M. (1984). Présence du Lias et de jurassique moyen sur le versant Nord du Haut Atlas de Marrakech (Maroc). Histoire paléogéographique. CR. Acad. Sci., Paris, 299 : 351356.

10. Michard, A. (1976). Éléments de géologie marocaine.

11. Beauchamp, J. (1984). Le Carbonifère inferieur des Jebilet et de l'Atlas de Marrakech (Maroc) ; migration et comblement d'un bassin marin. Bulletin de la Société Géologique de France, 7(6), 1025-1032.

12. Eddebbi A. (1989) - Etude sédimentologique et structurale de Carbonifère inférieur de la bordure nord du Haut Atlas de Marrakech (Foudrar et Souktana).

13. Mlih, A. B., Laâdila, M., El Kochri, A., El Youssi, M., \& Nassili, M. (2004). Le remplissage synrift au permien et au trias du bassin Tahanaout (Haut Atlas de Marrakech, Maroc) géodynamique et organisation sédimentaire. Estudios geológicos, 60(3-6), 123-138.

14. Salomon, J., Chellai, E. H., Guerra oui, F., \& Lang, J. (1996). Dynamique sédimentaire et structuration, durant le Néogène, de la bordure nord du Haut Atlas Marocain (Haouz de Marrakech). Journal of African Earth Sciences, 22(3), 323-3 


\section{Appendix}
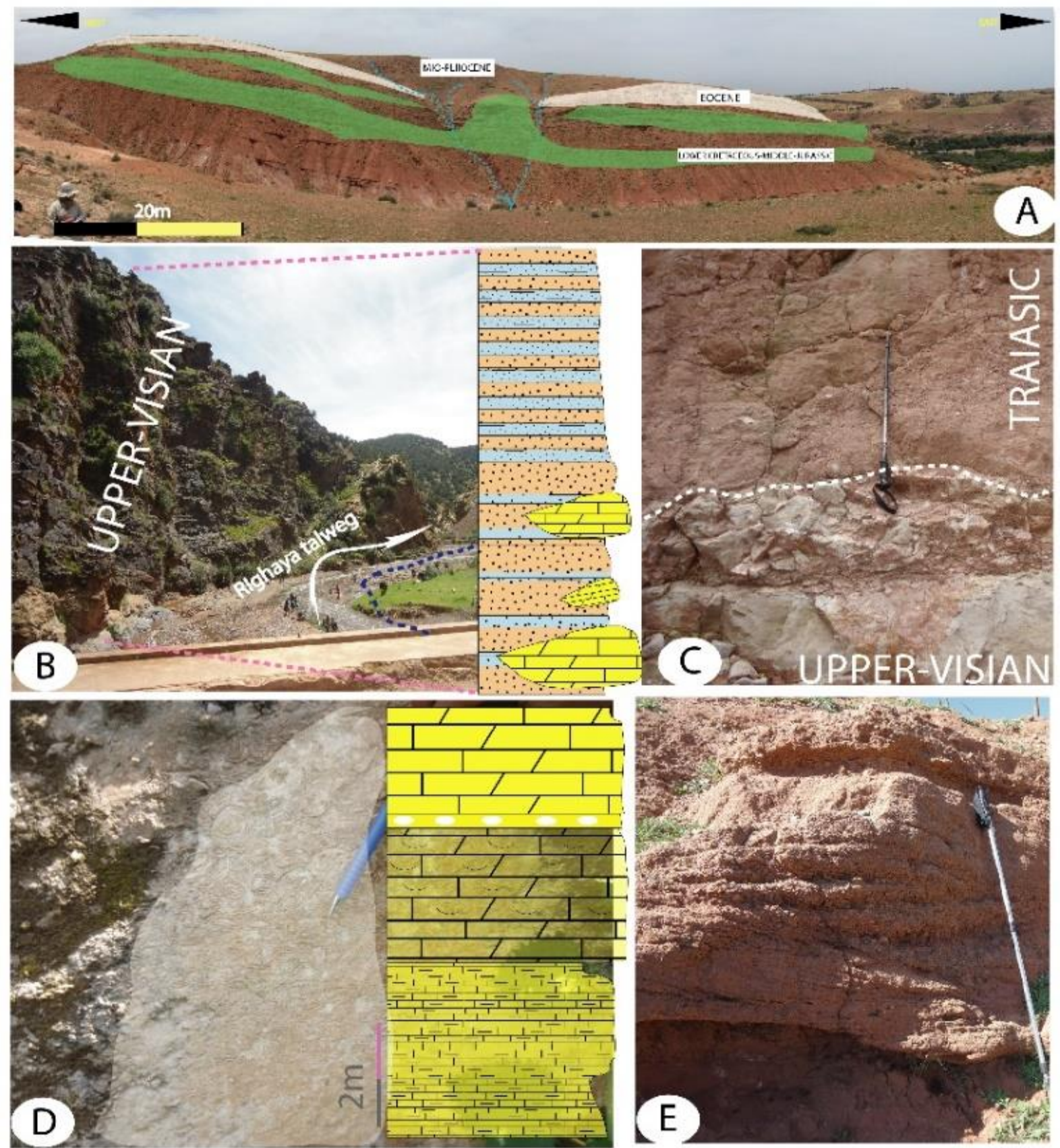

Note. Plate illustrates some aspects of the different lithologies studied in the TAHNAOUT basin.

A. The photo shows the triple point of three formations (Eocene,

D. Eocene fossilized plate,

Moi-Pliocene and upper Cretaceous),

B. Upper Visian outcrop with greying color above the level of L'OUED RIGHAYA,

E. The alternation of sandstone and conglomerate with the presence of lenticular forms indicates a deposit in an agitated environment at the Trias site.

C. Abnormal contact (angular discordance) between Trias and the basement which is formed by the Upper Visian, 